\title{
The Western Middle Classes under Stress: Welfare State Retrenchments, Globalization, and Declining Returns to Education ${ }^{1}$
}

\author{
L. CHAUVEL*
}

\begin{abstract}
*Louis Chauvel-Professor, Head of the Institute for Research on Socio-Economic Inequality (IRSEI), University of Luxembourg; Associate Researcher, Observatoire Sociologique du Changement (OSC) Sciences-Po Paris. Address: MSH 11 porte des Sciences, 4366, Esch-Belval, Luxembourg. E-mail: louis.chauvel@uni.lu

Citation: Chauvel L. (2020) The Western Middle Classes under Stress: Welfare State Retrenchments, Globalization, and Declining Returns to Education. Mir Rossii, vol. 29, no 4, pp. 85-111. DOI: 10.17323/1811-038X-2020-29-4-85-111
\end{abstract}

Following the work of Pierre Bourdieu and Gustav Schmoller before him, the multipolarity of the middle classes between higher and lower, and between cultural and economic capitals is well acknowledged. This old vision is useful to understand the "middle classes adrift" of the last 20 years in France and Continental Europe. The expansion of the "new wage earner middle class" of the 1960s to $1990 \mathrm{~s}$ is now an old dream of the welfare state expansion of Western societies, and the European social structure now faces a trend of "repatrimonialization", meaning a U-turn towards a decline in the value of mid-qualified work and an expansion of the return to the inheritance of family assets.

This paper addresses three main points. First, a new description of repatrimonialization is useful in the specific European context of middle-class societies. We need a redefinition of the system of middle classes (plural) in the context of the construction and decline of strong welfare states.

Second, there are three ruptures in the social trends of the 'wage earner society' of the 1960s to 1990s. In this period, economic growth, social homogenization and social protection were major contextual elements of the expansion of 'the new middle class, 'based on educational meritocracy, the valorization of credentialed skills, and the expansion of the average wage compared to housing and capital assets ('depatrimonialization'). After the 1990s, the rupture

\footnotetext{
1 I am deeply indebted to Katherine Newman and Paul Attewell for their long-term project of comparative middle-class dynamics that begun more than 20 years ago. Janet Gornick offered strong support with the Stone Center in CUNY, and opportunities to publish on middle-class dynamics. The most important debt goes to the organisers of the conference on the Middle Class on 9 October 2019 at the National Research University Higher School of Economics, in particular to Prof. Lilia Ovcharova, Dr. Svetlana Mareeva, and Dr. Olga Voron for their expertise, support and debates.
} 
and reversal of these trends, with 'stagnation', 'new inequalities' and 'social uncertainty' as new trends, generated a backlash in the "middle class society".

Third, I analyze the demographic and social consequences of these new trends in terms of the shrinking of the middle classes in a context where the inheritance of assets and resources changed the previous equilibrium. Finally, I highlight the importance of addressing the problem of social stability when large strata of the middle class have less interest in the maintenance of the social order.

Key words: middle class, inequalities, wealth, welfare state, social trends, generations, class system

According to international social indicators and comparative statistics, most Continental European countries are comfortable, intermediate middle-class societies under the protection of strong and stable welfare states. France is a noteworthy case-for the last thirty years, the French Gini index and interdecile ratio of post-taxes and postsocial-transfers incomes has remained relatively stable and low, the level of public employment and the number of civil servants show the remarkable permanence of the State, and welfare indicators and the good health of the elderly population illustrate the efficiency of the French 'new' middle class model of society. We could insist that deep French specificities such as the valorization of leisure, the priority to family equilibrium (with a fertility rate near to 2.0), the quality of collective childcare. Even if the French model appears stable, clear signs of destabilization have been surfacing in recent decades. These signs of long-term destabilization have observable effects in the political realm².

The most visible elements of this destabilization are the Yellow Vest Movement of 2018, the general expression of frustrations (Figure 1) and the long-term French systemic pessimism (Table 1). The intermediate middle class was also anxious about the European Union construction and development, seeing it as a Trojan horse for radical competition and the neo-liberal dismantlement of social protections. Twenty years ago, these fears were typical only among the working class fearing unemployment, but now they are shared by the middle class.

My intention here is not to participate in a polemical debate on the relative performances, priorities or fairness of the French model [Krugman 2005; Smith 2004; Guilluy 2016], or on European comfort and decline [Krugman 1994; Baverez 2003; Thelen 2014] or new challenges [Krugman 2009; Piketty 2020], but simply to elaborate on the stability and sustainability of the 'new' middle class society and discuss this paradox: why does a Continental European model of low inequality and strong State institutionalization seem to be so stable, when newer generations of young adults do not really benefit from its protection [Chauvel (1) 2006; Chauvel 2019]?

My first intention is to describe the Europe-specific structure of the middle class and develop a definition of the system of middle classes (plural) in the context of strong welfare states. I propose a redefinition of the system of middle classes.

\footnotetext{
2 The first to underline the fracture between the lower and upper middle class was Todd who described the increasing tensions between those, better educated, who benefited from the European union, and the victims of social change, in the context of the Referendum on the Maastricht Treaty, in September 1992.
} 
Table 1. Pessimism in Europe 2018 Eurobarometer 89.1

Answers to the question "Generally speaking, do you think that the life of those in the EU who are children today will be easier, more difficult or about the same as the life of those from your own generation?"

\begin{tabular}{|c|c|c|c|c|c|}
\hline & More difficult & About the same & Easier & Don't know & Total \\
\hline Belgium & 76.68 & 14.54 & 8.45 & 0.32 & 100 \\
\hline Luxembourg & 72.86 & 13.57 & 11.61 & 1.96 & 100 \\
\hline France & 67.54 & 19.78 & 10.17 & 2.51 & 100 \\
\hline Cyprus (Republic) & 60.72 & 20.52 & 16.01 & 2.75 & 100 \\
\hline Greece & 59.93 & 21.72 & 15.97 & 2.39 & 100 \\
\hline Spain & 58.96 & 16.19 & 23.18 & 1.67 & 100 \\
\hline Great Britain & 55.98 & 21.09 & 16.73 & 6.2 & 100 \\
\hline Northern Ireland & 55.98 & 17.42 & 14.64 & 11.95 & 100 \\
\hline Czech Republic & 54.53 & 28.69 & 14.36 & 2.42 & 100 \\
\hline Malta & 54.25 & 14.78 & 25.54 & 5.43 & 100 \\
\hline Germany-West & 52.34 & 28.7 & 15.92 & 3.05 & 100 \\
\hline The Netherlands & 51.33 & 30.72 & 16.34 & 1.6 & 100 \\
\hline Germany East & 51.23 & 27.28 & 16.49 & 4.99 & 100 \\
\hline Italy & 50.45 & 22.75 & 19.96 & 6.84 & 100 \\
\hline Slovenia & 49.2 & 30.12 & 18.32 & 2.36 & 100 \\
\hline Austria & 47.91 & 39.77 & 10.03 & 2.29 & 100 \\
\hline Slovakia & 47.28 & 30.64 & 15.19 & 6.89 & 100 \\
\hline Sweden & 46.13 & 31.66 & 20.65 & 1.56 & 100 \\
\hline Estonia & 44.99 & 19.22 & 30.32 & 5.47 & 100 \\
\hline Portugal & 43.25 & 17.23 & 37.27 & 2.26 & 100 \\
\hline Hungary & 42.51 & 21.35 & 32.55 & 3.6 & 100 \\
\hline Romania & 39.02 & 32.92 & 22.22 & 5.84 & 100 \\
\hline Ireland & 36.75 & 27.18 & 33.61 & 2.46 & 100 \\
\hline Denmark & 34.25 & 39.88 & 23.43 & 2.44 & 100 \\
\hline Finland & 33.08 & 37.48 & 28.14 & 1.3 & 100 \\
\hline Bulgaria & 30.71 & 27.09 & 25.54 & 16.66 & 100 \\
\hline Croatia & 28.56 & 38.92 & 29.96 & 2.56 & 100 \\
\hline Latvia & 27.11 & 28.35 & 41.14 & 3.4 & 100 \\
\hline Poland & 25.28 & 24.34 & 43.19 & 7.2 & 100 \\
\hline Lithuania & 23.74 & 25.93 & 47.09 & 3.24 & 100 \\
\hline All countries & 51.18 & 24.23 & 20.34 & 4.25 & 100 \\
\hline
\end{tabular}

Source: Special Eurobarometer 89.1 Spring 2018. Own computations. 
Figure 1. INSEE Indicator "Personal financial situation perspectives", differences between positive and negative answers, corrected for seasonal variations

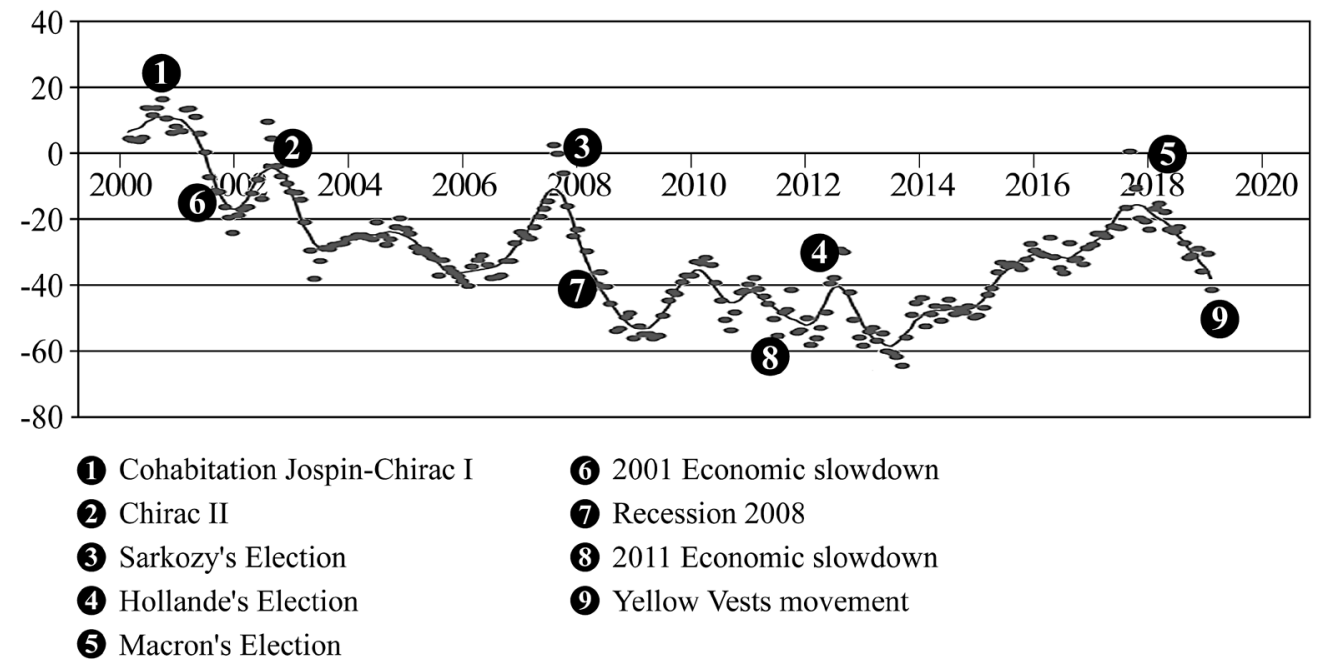

Note: the indicator describes French household perceptions of their own economic perspectives. Values are negative when a majority expresses pessimistic views.

Source: Data: INSEE; Own computations.

My second point is a presentation of three ruptures in the social trends of the "wage earner society" of the 1960s to 1990s. In this period, economic growth, social homogenization, and social protection were major contextual elements relevant to the expansion of the "new middle class", based on educational meritocracy, the valorization of credentialed skills, and the expansion of the average wage compared to assets ('depatrimonialization'). After the 1990s, the rupture and reversal of these trends in favor of new trends such as "stagnation", "new inequalities" and "social uncertainty," generated a backlash in the system of middle classes [Savage 2015].

My third point is to analyze the demographic and social consequences of these new trends in terms of the shrinking and quartering of the middle classes in a context where the inheritance of assets and resources ('repatrimonialization') changes the previous equilibrium. The problem of social stability in a context where large strata of the middle class have less interest in the stability of the social order must also be addressed.

\section{Europe as a realm of the middle class: past dreams, present paradise and a contemporary U-turn}

Form a very abstract point of view (Figure 2), when one considers economic inequalities ${ }^{3}$ in the world, France, like most countries of Continental and Nordic Europe, is a country

3 Of net per capita household income after redistributions. 
of equality and comfort: in terms of post-tax and post-transfer disposable income by consumption unit, it is not far from Finland, which is may be the most equal country in the world, and falls relatively close to Luxembourg, which is the richest country by per capita GDP in terms of purchasing power parity (PPP). A mapping of the degree of development and inequality in the world presents Europe as a club of rich and equalitarian nations. In fact, this vision of Europe in the early $21^{\text {st }}$ century is quite problematic because it does not reflect a new reality: Europe is no longer the union of 15 members sharing similar characteristics - rich, old-industrial western liberal democracies - it was in the early 1990s. Europe is now a set of 27 dissimilar countries where large new members do not share the same degree of economic, social, and human development.

Figure 2. Degree of development (horizontal axis) and inequality (vertical axis) in 2015

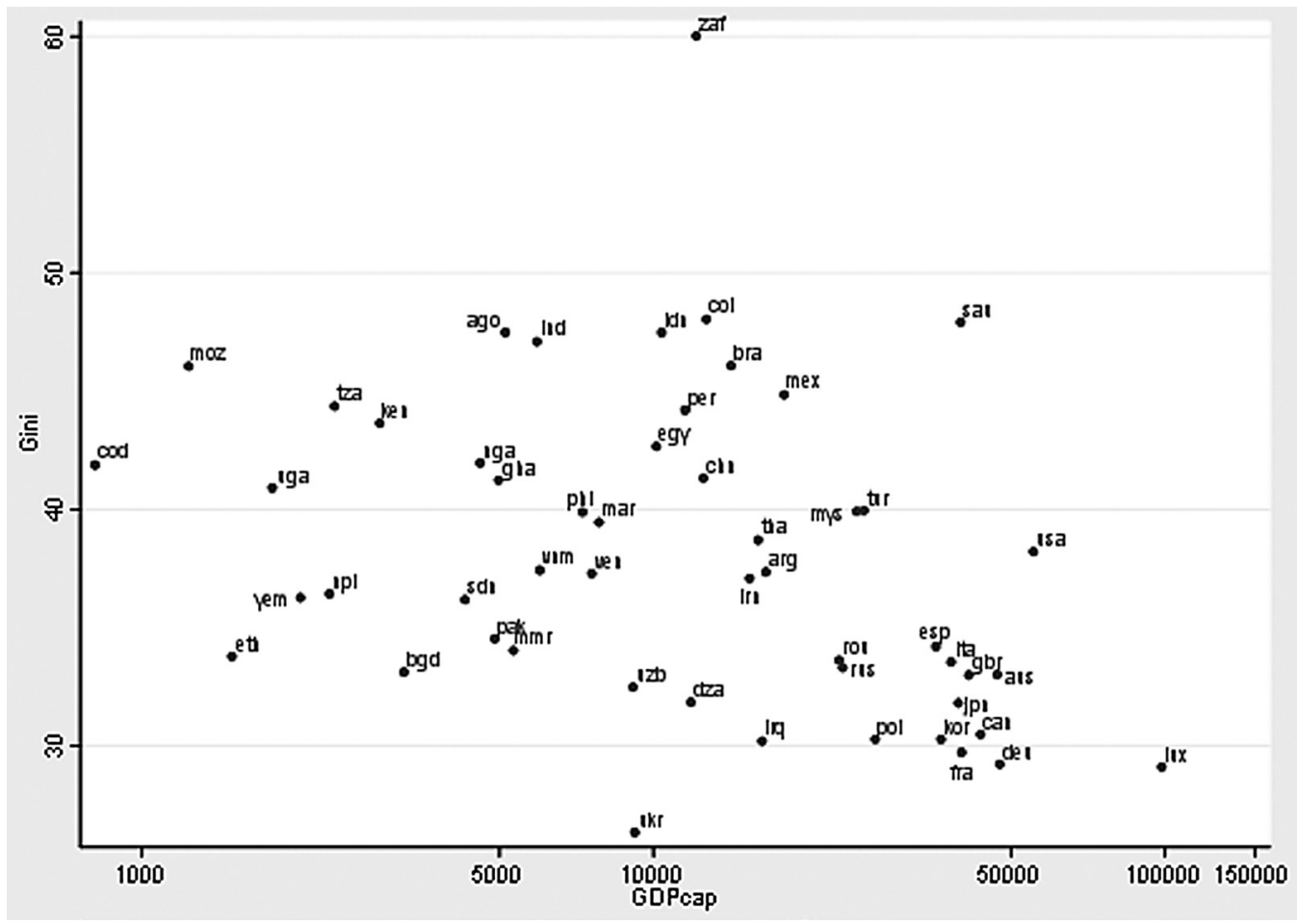

Source: X-axis: GDP per capita in PPP \$ from Penn World Tables 9.1 for average incomes; Y-axis, Gini indices for income according to SWIID v8. The dots represent the standard ISO country codes 3 characters (https://en.wikipedia.org/wiki/List_of_ISO_3166_country_codes). Countries with more than 20 million inhabitants, plus Luxembourg

By comparing the old and the new members of the EU (including Romania and Bulgaria), we can clearly see the differences between the two projects. This is simply one example of globalization in the old European countries, where the expansion of the "outside Europe" markets fosters competition with new industrial countries with low labor costs. "Inside Europe" competition (where import/export taxes are reduced, 
and transaction costs are reduced to transportation costs alone) contributes to more capital volatility, competition between workers and in investment opportunities, and a polarization in the marginal productivity of wage earners between specialists and managers on the one hand and ordinary workers on the other. A decisive aspect of the social development in the world in the recent decades is the economic dynamics in relation to educational development: with progress in investment in schools and universities, populations are more educated, but the correspondence in terms of economic development reveals extreme distortions (Figure 2bis). More educated countries are generally more developed, but with exceptions. Due to extreme difficulties in the early 1990s in the transition from soviet era to the new Russian Federation, the structure of relations between education and income had been deeply destabilized before 2000, but a major recovery happened in the 2010s. Conversely, in most Western societies, the boom in education in the period 2000-2015 had no major impact on incomes, generating increasing gaps between higher education and stagnating wages, and then frustrations and the subsequent signs of anomie. With the trend in Figure 2bis, we might envisage a coming convergence between Russia and the West.

Figure 2bis. Average level of education (horizontal axis) and economic development (vertical axis) from 2000 to 2015 in the 20 largest countries in the world (plus Luxembourg)

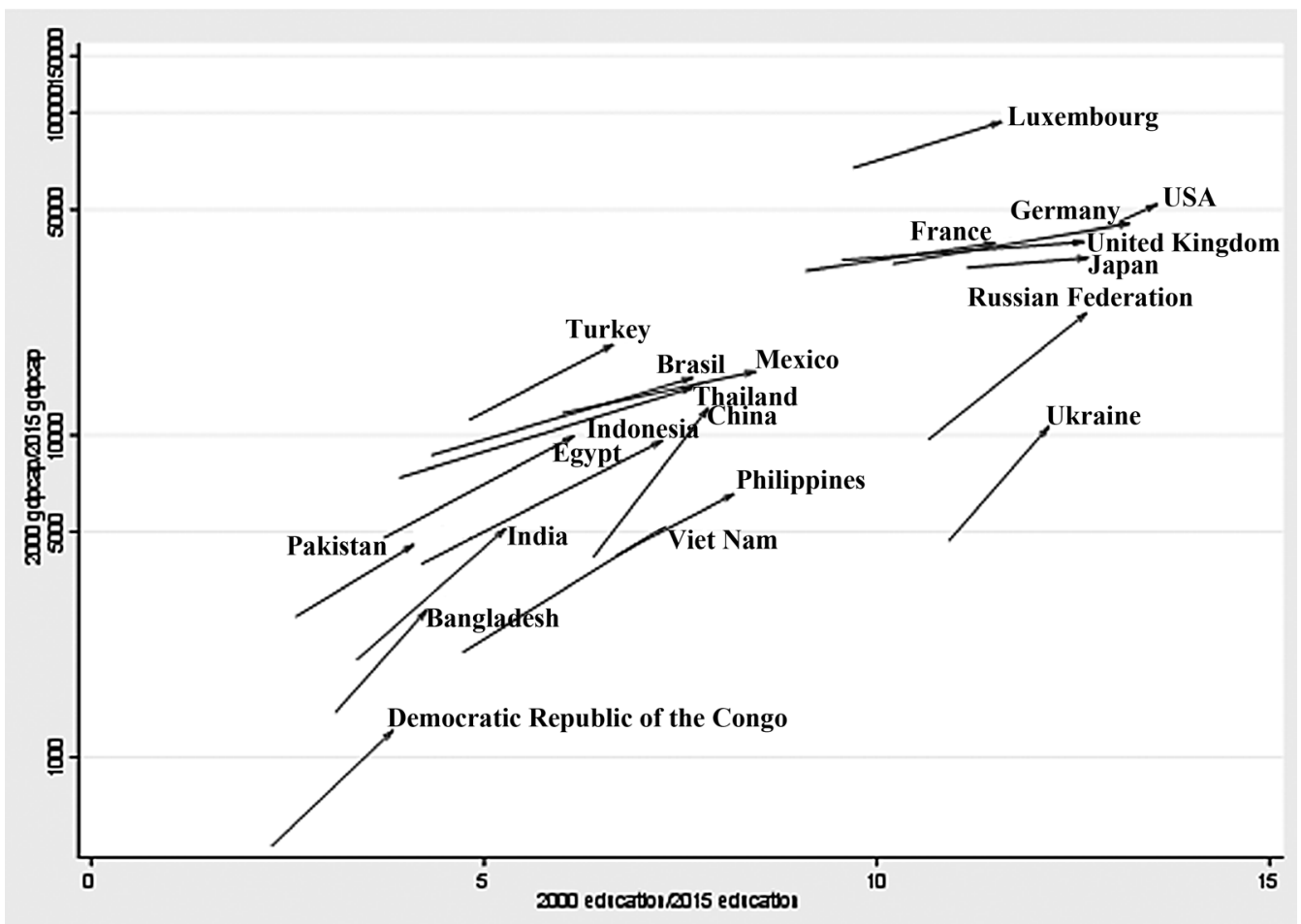

Source: X-axis, average number of years of education (Barrow-Lee datasets: http://www.barrolee.com/); Y-axis: GDP per capita in PPP \$ (log scale) from Penn World Tables 9.1 for average incomes. Arrows represent the trajectory from 2000 to 2015 . 
Figure 3. Dynamics of income and of inequality 1995-2015 in the 20 largest countries in the world

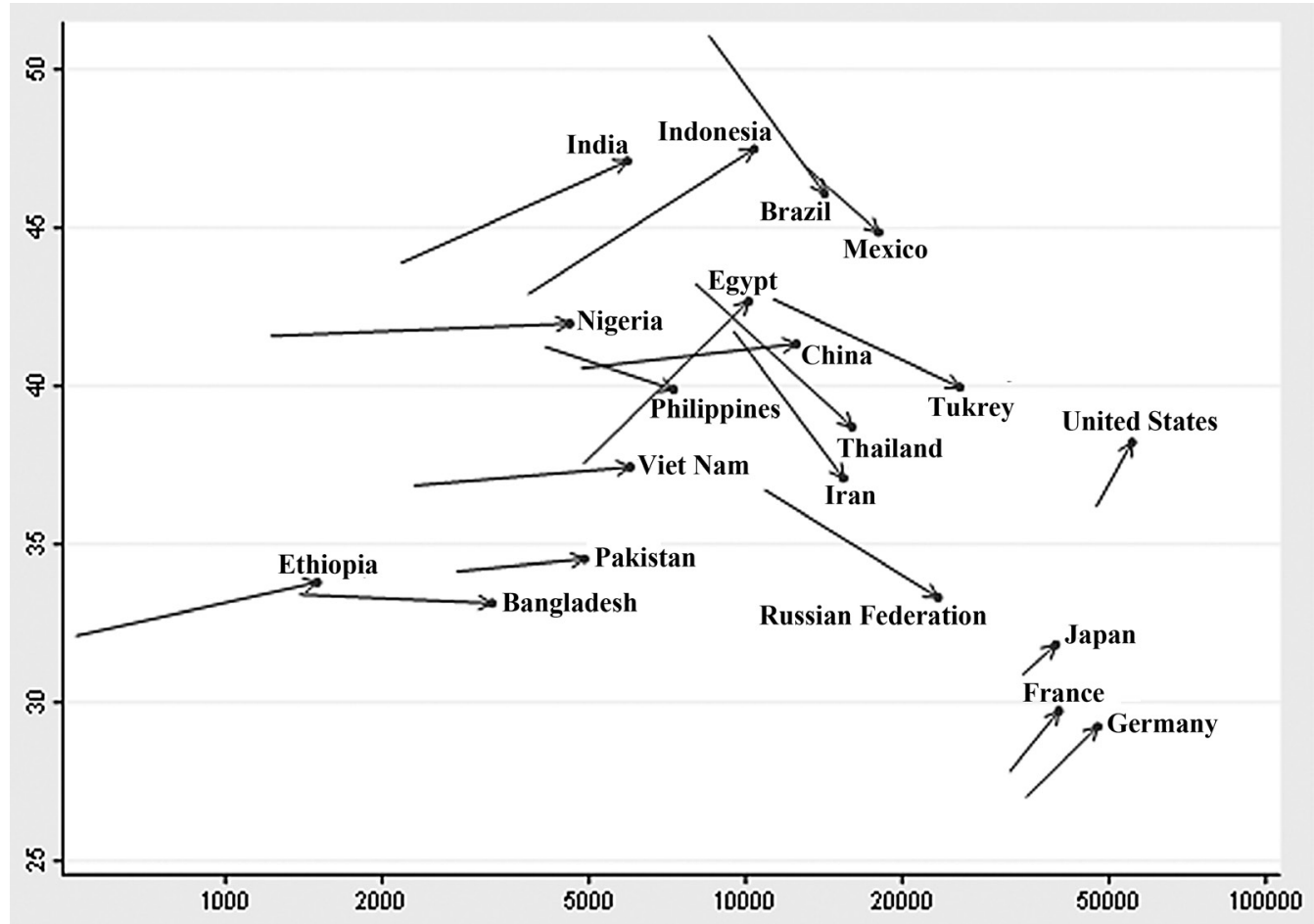

Source: X-axis: GDP per capita in PPP \$ from Penn World Tables 9.1 for average incomes; Y-axis: Gini indices for income according to SWIID v8.

The new global trends that took off between the mid-1990s and the mid-2010s (Figure 3) further help to explain the unequal dynamics inside and outside the EU. Most larger European nations, along with Japan and the US, experienced a slow transformation or even stagnation in both growth and inequality, large nations in the rest of the word changed rapidly: Russia increased its relatively moderate income inequality, paralleled by Turkey; China, Indonesia, and Egypt expanded with increasing inequality.

France is an average nation in the European club of comfortable and equal countries, but in its stability in terms of economic inequalities it is not ${ }^{4}$. Compared to the more liberal regimes (UK, US, etc.) of the three worlds of welfare capitalism [EspingAndersen 1990], which are structurally more unequal and becoming more economically polarized, and compared to the social democratic regimes (e.g. Sweden), where, since the end of the 1990s, the most celebrated equalitarian countries of the world have been facing increased economic inequality, France's Gini coefficient remains static.

4 Because of stronger redistributions balancing lower income in the lower strata of the working class. 
This French mix of moderate inequalities ${ }^{5}$ and the lack of a clearchange in income inequality is a fundamental trait of the French welfare regime, based on a strongly institutionalized (i.e. state-organized) middle class. Here one of the most significant problems of international comparison becomes relevant: how can we define the "middle class" in a comparative context [Zunz, Schuppa, Hiwatari 2002; Mau 2015]?

An international definition is almost impossible, because two incompatible approaches to defining the middle class exist. In the first approach, characteristic of British sociological discourse, the middle class (singular) refers to a comfortable group, located immediately below the upper classes. In the second approach, which is more common in Continental Europe and in the American golden age of the 1960s [Mills 1951], the middle classes (plural) represent an aggregation of intermediate groups, whose incomes are close to the arithmetic mean. The first approach is more elitist, with the "middle class" representing at most $5-10 \%$ of the population; the second approach has the potential for inclusivity among the middle classes, with an ideal of two-thirds of society (in Germany: Zwei-Drittel-Gesellschaft) where the middle class aggregates the most stable and qualified wage earners, and represents between 50 and $80 \%$ of the population. These competing definitions are a major source of uncertainty in the discourse on the middle class.

One of the first appearances of this distinction emerged with the French social thinker who profoundly inspired Pierre Bourdieu: Edmond Goblot. In his book, La Barrière et le Niveau (The Fence and the Level), Goblot describes the British middle class in the following way: "It has large incomes, is affluent and comfortable, and is served by an abundant domesticity in luxurious mansions. It is called "middle" 6 because the aristocracy (the upper class [in English in the text]) subsists. In England, the class which is at the level of our middle classes cannot be distinguished from the popular classes" [Goblot 1925, pp. 21-22]. The British 'middle class' is much richer than its Continental European homonym.

The French and Continental European terminology of "middle classes" (French: classes moyennes, German: Mittelstand, Spanish: Classes Medias, etc.) is often translated as 'the lower middle class' in the English tradition [Mayer 1975]; conversely, the English debates on the 'middle class', notably in terms of gentrification [Butler 2003], refer to a social group that, in terms of education, income, and wealth, is clearly above the standard Continental European middle class. However, in the political discourse, this terminological confusion is very common in countries where most politicians claim they represent the interests of the (lower) middle class, seen as the most central and numerous social group for gaining democratic legitimacy, but gear their economic policies (tax cuts, the design of social redistributions, etc.) towards the upper middle class [Skocpol 2000; Gornick, Jäntti 2013], to which most political leaders actually belong.

Beyond this problem of the translation of basic concepts, the link between the degree of inequality and the shape of the system of social stratification remains loosely developed in a comparative context. It is difficult to understand the social architecture resulting from the intensity of inequalities, notably in terms of the economic coherence

\footnotetext{
5 In terms of post-tax, post-transfer income per capita.

6 In French, there is ambiguity in the term classe moyenne since moyenne is both 'middle' and 'average'.
} 
of the middle class. A solution is the analysis of the shape (Figure 4) of the "strobiloid" curve [Chauvel 1995; Chauvel 2016], which is the smoothed density of the medianized income (defined as the post-tax and post-transfer income by consumption unit); a curve which is adapted to international comparisons (Figure 5).

Figure 4. The strobiloid representation of income distribution

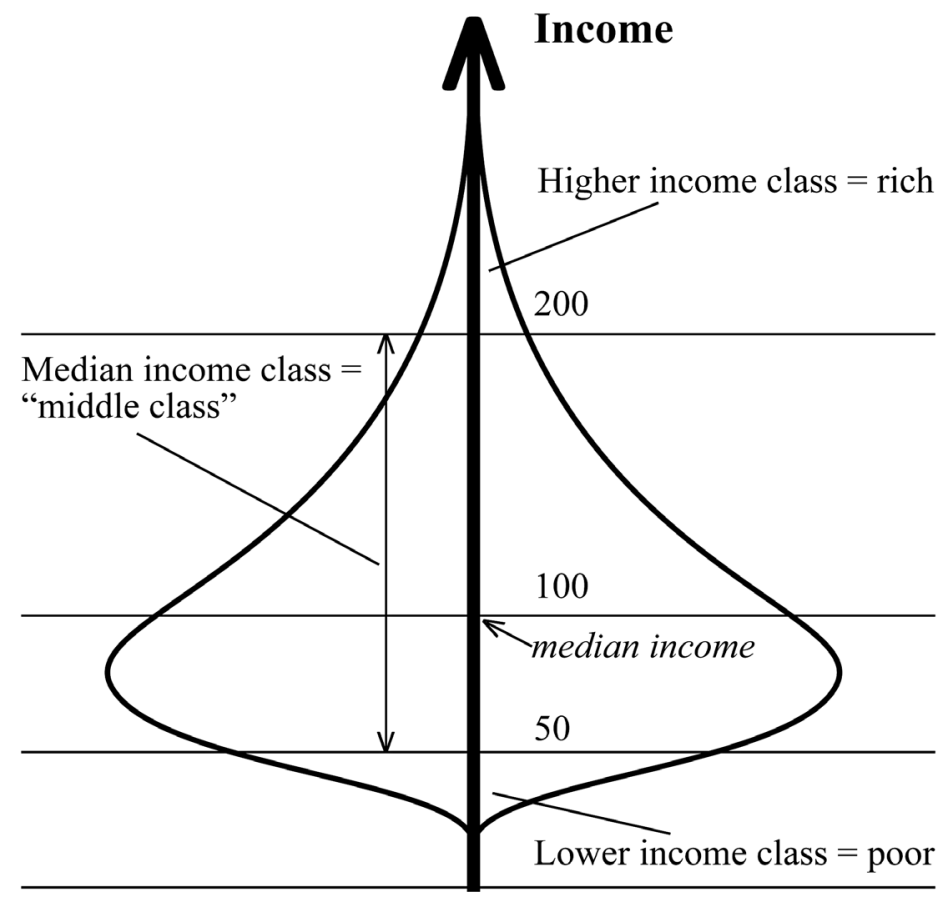

Note: In the strobiloid curve, income is the vertical axis; 100 is the median income. Generally, the curve is narrow at the top and at the bottom (few people are extremely poor or extremely rich). The larger the curve around income $=100$, the more median class the population.

For this comparison, the two opposite poles of the international spectrum of inequalities offer interesting points of reference: Sweden, with a Gini coefficient of $25.2 \%$, one of the lowest in the world, and Brazil, with a Gini coefficient of $59.8 \%$. In Sweden, since the floor (the poor) is high and the ceiling (the rich) is relatively low, the larger part of the population is amassed near the median. If we define 'the median class' as the population between half the median and twice the median, $84 \%$ of the population is between these borders. In Brazil there is a strong polarization between the extremely poor, with incomes near zero, and extremely rich. There, the median class consists of approximately $44 \%$ of the population. The US stands in an intermediate position between these two extremes, with $58 \%$ of the population in the median class. The French strobiloid (see the left hand side of Figure 6) is closer to the Swedish one, even if its median class is less homogeneous and concentrated near the median. 
Figure 5. Comparisons of national strobiloids

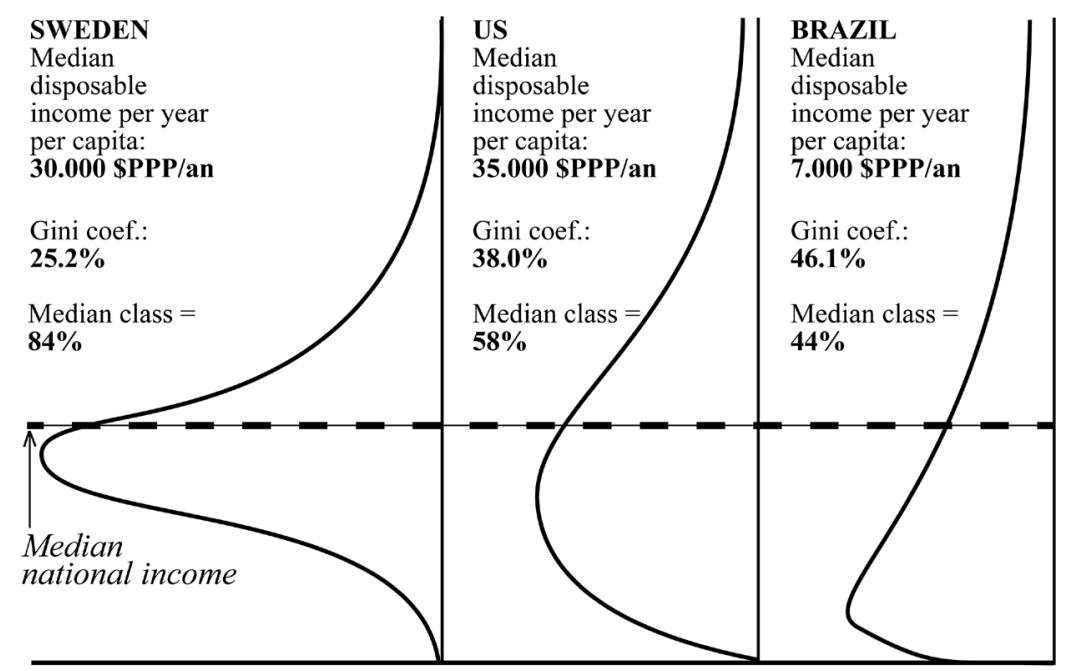

Figure 6. Income and Wealth Strobiloid 2017 in euro (in France)

$100=$ Median Income

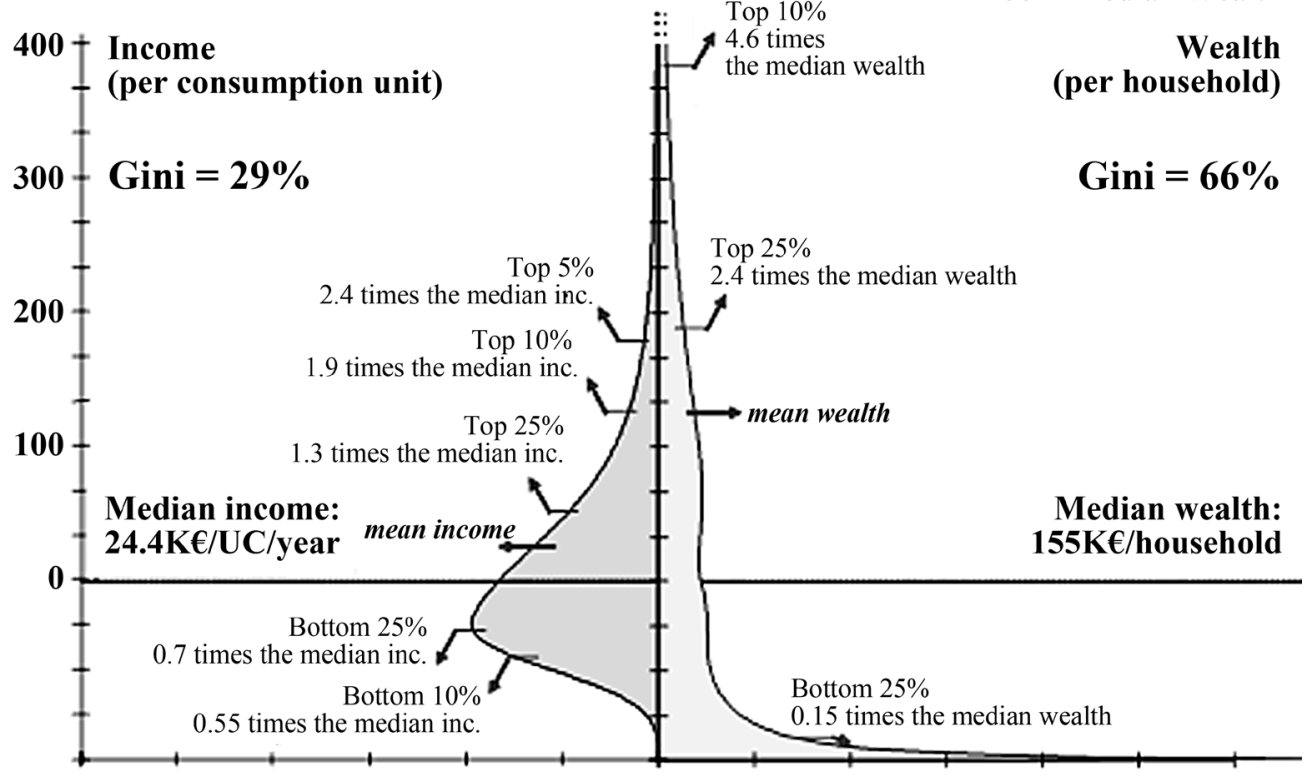

Note: The strobiloid is the shape of social pyramid corresponding to the distribution of income (left half) versus wealth (right half) (see [Chauvel 1995]). At a given level of income, the larger the curve, the more people there are positioned around this point. If 100 is the median income (per consumption unit) a large strobiloid at level 100 shows a large middle class at an equal distance between extremes. For wealth, there is clearly no middle class, and the population is stretched between an extremely high level of accumulation and an extremely low level.

Source: income: EU-SILC 2017; Wealth : EU-HFCS wave 2017 in current Kilo-euros (1000 euros). 
Another aspect of economic inequality is the difference between the flow (income) and the stock (accumulated wealth), which generates different extreme inequalities [Killewald, Pfeffer, Schachner 2017; Kuypers, Marx 2018]. In France, if we compare the Gini coefficient for income (29\%) and the one for wealth $(75 \%)$, and the shapes of the associated strobiloids, two different pictures appear. In terms of income, France is a country with a strong homogeneous "median class", while in terms of wealth, a strong polarization exists between no-wealth families and the top of the strobiloid, which shows no homogeneous median class (Figure 6). This distribution can explain part of the terminological ambiguity about 'the middle class', in the English and Continental European traditions: in French, 'the middle class' means the population of common citizens with normal incomes, needs, lifestyles and consumption patterns, but in English, it defines the intermediate group between the highest economic elite based on wealth accumulation. In France, 'the middle class' is a kind of 'average income class', while in the English tradition it refers to much higher positions - individuals with above average wealth.

\section{A reconstruction of the definition of the middle class}

As explained above, the empirical presentation of the French stratification system lacks a theoretical basis and confusion exists surrounding the definition of 'the middle class'. In light of this, we need a theoretically grounded reconstruction of the concept. To resolve this conceptual ambiguity, we return to the German social sciences of the end of the $19^{\text {th }}$ century, when the notion of the middle class (Mittelstand) emerged along with a conceptualization of the diversities of the middle classes. This early literature elaborated a typology able to underline the specific role of 'the new middle class' (neue Mittelstand). The late $19^{\text {th }}$ century German context is clearly different from the contemporary French one [Charle 2002]; Wilhelm's Germany had been facing rapid socioeconomic modernization during the final three decades of the $19^{\text {th }}$ century, and was about to, in a generation, transform (even if the impact was regionally heterogeneous) Germany from a feudal society to a complex industrial society.

These considerable changes were deeply influenced by the contrast between archaic cultural traits and representations (for example, the notion of Mittelstand, refers to an 'intermediate State' similar to the French 'Tiers Etat' of the $18^{\text {th }}$ century) and the surprising rapidity of the socio-structural transformation. These deep cultural transformations were extensively described by Simmel [Simmel 1905] who paid particular attention to this new specific social group able to subvert the old class conflict between the elite and the working class, meaning a profound complexification of social relations and solidarities. The transformations of the social structure were marked by industrialization and the expansion of elaborate bureaucratic organizations, such as the constitution of a new and strong central state and with the expansion of industry and services (insurance, banks, post offices, etc.). Inside the German social democratic party, these social transformations produced a new debate on the (in)accuracy of the Marxist prophecy of relative or absolute proletarianization, a sociological diagnosis that Bernstein [Bernstein 1899] was the first to translate in political terms.

However, two years earlier, Schmoller [Schmoller 1897] was the first to face this difficulty in a seminal text that anticipated further sociological problems and diagnoses 
of the social structure. Schmoller underlined the existence of two important dimensions structuring the middle class space:

- he highlighted the distinction between an Obere and an Untere Mittelstand an upper and lower middle class. This distinction underlined the hierarchical division of the middle classes, the Obere reaching the limits of aristocracy, and the Untere neighboring the working class;

- he also developed the polarization between an Alte and a Neue Mittelstand. The Alte consisted of intermediate farmers, self-employed shopkeepers, small business owners, while the Neue benefitted from the fast expansion of a social group of qualified wage earners in industry, large service companies, and state (Beamten) and private bureaucracy (Angestelten) [Kocka 1981].

Schmoller's distinction between the Alte and Neue Mittelstand underlines the emergence of an important concept - the new middle class. Lederer and Marschak [Lederer, Marschak 1926] and Geiger [Geiger 1932] wrote on the destabilization of the new middle class in the post-First World War context, and in White Collar: The American Middle Class [Mills 1951], Mills analyzed the contemporary American model of the middle class. The debate between emergence or the pauperization of the middle class during the difficulties of the 1914-1950 era reveal a long pause in the process of middle-class expansion, particularly in Germany.

In contemporary analyses of the middle classes, the dimensions of Upper/Lower and Old/New remain useful. These two dimensions are complementary (Figure 7) and offer an analytic image of four large sets of middle classes. With these two axes, Schmoller prepared the Bourdieusian idea of a two-dimensional social space [Bourdieu 1979] 70 years in advance. When these two axes of differentiation inside the middle class are crossed, the two-dimensional social space provides four types of middle classes:

Figure 7. The bidimensional space and four types of middle classes

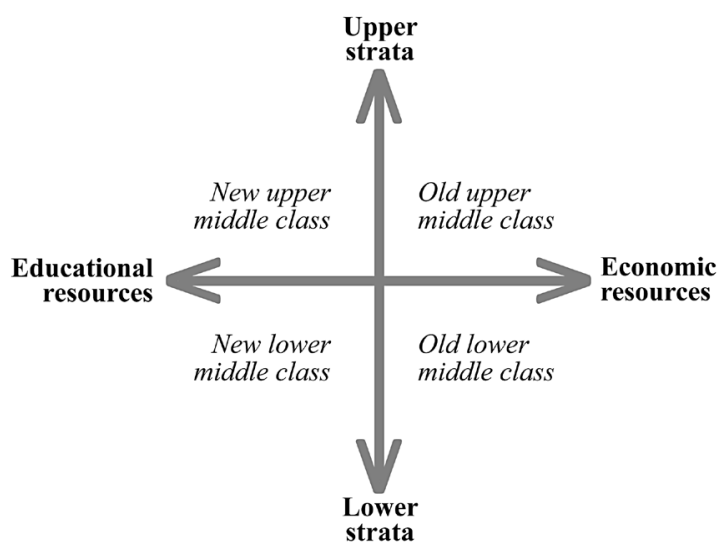

The old middle class refers to small owners and a petty bourgeoisie who own small property. The old upper middle class consists of neighboring aristocrats and large proprietors. Typically, medium size entrepreneurs are the ideal type of the old middle 
class, in which patrimony (both in terms of wealth accumulation and inheritable shares of economic control of production) is the strategic model. Higher civil servants in the traditional services of the state ("Fonctions régaliennes de l'Etat"), such as homeland security, police, and the central bank, and groups that are considered extensions of the former aristocracy, such as higher military officers, are situated in the old upper middle class. Members of the "haute bourgeoisie" (large proprietors) ${ }^{7}$ are also sometimes classified as members of this group. Self-employed individuals without employees, specifically those in manual occupations, are typical of the old lower middle class. For Schmoller, two new types emerged in this sociological stratification. The first is a new lower middle class of wage earners in occupations based on an intermediate level of responsibility or technical qualification, such as low-level engineers, semiprocessionals, low-level managers, and most of the intermediate bureaucracy of the state and large companies. The second is a new higher middle class, defined by expertise, the control of larger organizations, elaborate knowledge, the symbolic manipulation of complex systems, management, ruling, and decision making. Schmoller is the first social scientist to have clearly detected the expansion of a social stratum based not on patrimony. The opposition between the old and new middle classes appears to be, first, a question of credentialed skills and the control of complex and institutionalized knowledge, which is mainly technical, juridical or more generally certified by qualifications controlled by a professional group recognized by the state (in the French context). On the contrary, the old middle classes are more closely tied to the control of economic resources and are directly dependent on markets. These divisions are acknowledged through a socio-professional classification that is deeply internalized by any wage earner8.

The depatrimonialization of economic positions, a return to credentialed skills [Wright, Dwyer 2003] and strategic knowledge clearly emerged in the post-Second World War era, particularly in Europe, when the wage earning middle class was about to access higher statuses, better market positions, and more social protections and political control, without the accumulation of economic resources but with the accumulation of cultural capital, credentialed skills, state-recognized social rights, and political recognition [Castel, Haroche 2001]. However, as this trend reversed in the last 20 years in favor of repatrimonialization, Europe has been experiencing a backlash.

\section{The declining returns to education}

In international debates on 'the value of education' and overeducation [Collins 2019], the French or Latin European notion of 'inflation des diplômes' (qualification) seems to be an exception [Duru-Bellat 2006; Chauvel (2) 2006; Bar-Haim, Chauvel, Hartung 2019].

\footnotetext{
Supposed to control larger assets, and based on intergenerational strategies of wealth transmission and reproduction.

8 In the French statistical system, these "socio-professional categories" or "socio-occupational groups" CSP are a type of official classification of occupations, with no alternative and that no one can avoid [Desrosières, Thévenot 1988; Szreter 1993]. 'Cadres' (= senior wage earner managers, experts of professionals) are similar to the "higher service class of the EGP scheme; 'professions intermédiaires' are second-rank professionals and managers, and can be roughly identified to the lower service class of the EGP scheme; 'employés' are routine white-collar and service workers; 'ouvriers' are blue-collar workers; 'agriculteurs' and 'patrons' are the self-employed in agriculture and of other sectors respectively. This nomenclature is widely used by official and private statistical agencies and constitutes a tool broadly adopted by individuals to describe their own social position.
} 
We have no room here to develop these, but the main issue in France, with an extreme form of the socio-generational fracture between birth cohorts, is that we have the simultaneity of two contradictory trends - the new cohorts of young adults are becoming more educated while the social structure remains stable, with a slow increase in social upgrading9.

Figure 8. Educational inflation - access to upper and intermediate middle-class positions by levels of education $1965-2012, \%$

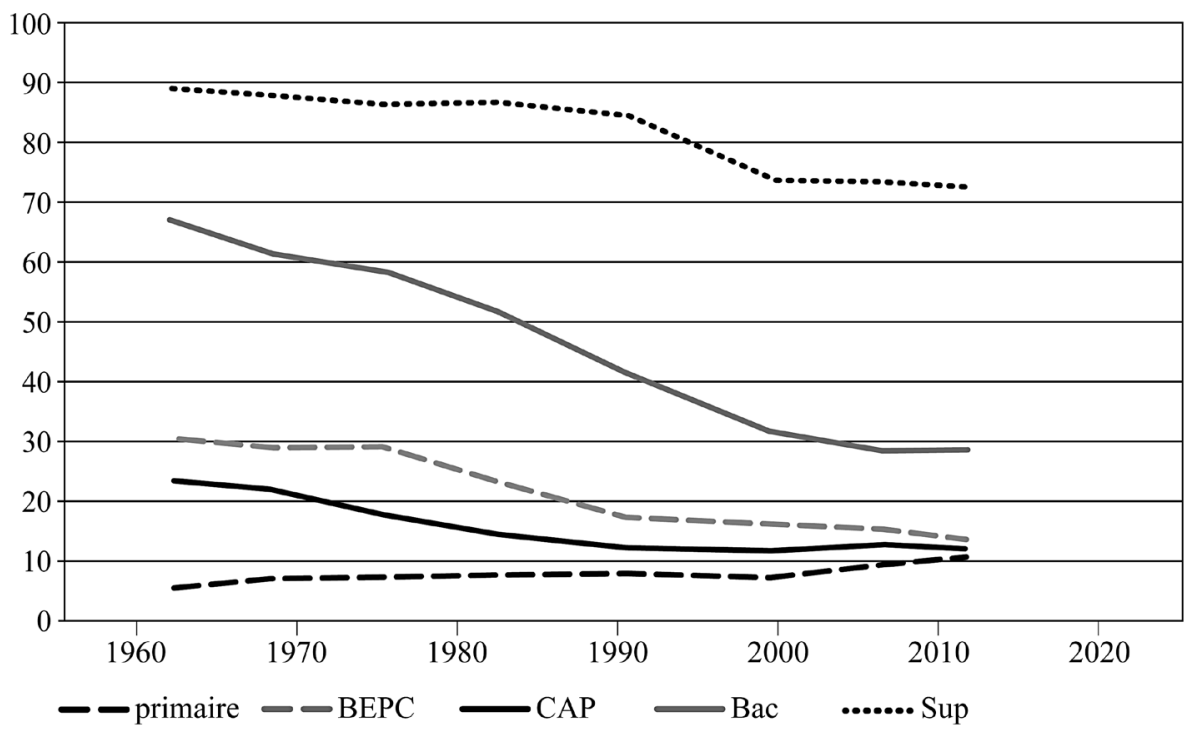

Note: Primaire - primary school or no formal education, BEPC - Lower secondary school, CAP - Vocational secondary school diploma, Bac - Classical secondary school diploma, Sup - Higher education diploma.

Source: French censuses microdata from: Minnesota Population Center, Integrated Public Use Microdata Series, International: Version 6.1 [Machine-readable database], Minneapolis, University of Minnesota, 2016. Author's computations.

The expansion and ultimate overcrowding of the (mid) educated population results from the two contradictory trends. The result is the qualification inflation effect, which comes with the risk of 'educational downgrading' ${ }^{10}$ (déclassement éducationnel). This downgrading involves the intrinsic value of (intermediate level) qualifications declining from cohort to cohort in terms of the probability of access to higher or middle positions. The youngest generations of adults received, on average, three more years of education than their parents, and yet have lower socioeconomic positions than their parents when the latter entered adulthood 30 years earlier (Figure 8). This problem of downgrading (and its increasing social visibility) helps to explain the pessimistic outlook in France and continental and southern European countries.

\footnotetext{
9 Upgrading is defined here as a shift of social structure where higher occupational groups expands when lower ones declines in size.

10 This expression means that the new cohorts find lower social positions than expected (if the scale of educational values of parents remained unchanged).
} 


\section{The socio-eco-demographic crisis of the new middle class}

In this section, I highlight the origin of the mismatch between educational attainment and social position. When we compare the 'old style' middleization (i.e. the trend of expansion of the middle class) of the industrial (or early post-industrial) society to the more recent one, the problem of the so-called new middle class emerges. Post-1960, the expansion of the new middle class was seen as an inherent trend of modernity [Mendras 1988]. Despite Mills positing a fundamental political conservatism and instability within this class ${ }^{11}$, from the late 1960 s to the mid-1990s, more optimistic analysts hypothesized a softcultural revolution brought on by the 'nouvelle classe moyennesalariée' (the new wage-earning middle class, [Touraine 1969]). The declining intensity of class cleavages was about to blur class borders [Aron 1969]. Strong debates emerged such as the controversy between Bourdieu [Bourdieu 1979], who claimed that the "dominated fractions of the dominant classes' were intrinsically frustrated by their ambiguous position, and Bidou [Bidou 1984], who demonstrated that during the late 1970s, young members of the new middle classes were bringing a new culture of self fulfilment and emerged as central political actors, mainly at the local level.

The cultural dynamics of the new middle class was based first on the spectacular growth of this social category. During the Trente Glorieuses (1945-1975, see [Fourastié 1979]) era of full employment and rapid growth (annual growth of about $4 \%$ for the worker's real wages), the French state fostered a model of a welfare regime that employed a large middle class population in public services about to improve health, education, and human development. It also developed large-scale interventions in the industrial and service economy, nationalizing or launching public companies which engaged a large technical and service middle class in businesses and infrastructure such as transport and electricity, State owned mega companies (SNCF, EDF), high tech companies in the nuclear industry, telecommunications and space (CEA, PTT, Aérospatiale), strategic industries (the automobile industry, steel, mining), banks, and insurance. In short, the trend was towards the protection of wage earners in a salaried society [Aglietta, Brender 1984]. From these policies emerged a trend of moyennisation (middleization) [Mendras 1988] that increased the percentage of the population that was in the "higher service class" from $4.3 \%$ to $11.8 \%$, and the "lower service class" from $12.5 \%$ to $25 \%$ between 1969 and 2015 . The rapid growth of these populations created an optimistic outlook among the middle class; concerns about poverty, downward mobility, unemployment and exploitation declined. However, after 1984 and the conversion of the government elites from both left and right political moderate parties to monetarism and public debt control, the capacity to fuel this middle-class expansion disappeared.

Since 1982, the size of the middle classes has remained the same, constituting about $30 \%$ of the 20 to 59 year-old population. The most important change in the middle class has been the redistribution from public to private status. Even if the public higher service class prolongs its expansion, the downward trend of the public lower service class

\footnotetext{
11 Mills, who had been translated into French in 1970, read Lederer and Marschak [Lederer, Marschak 1926], who were the first to systematically analyze the destabilisation of the 'new middle class' in post-WWI Germany [Mills 1951, p. 357]. However, Mills ignored Geiger's contribution [Geiger 1932] on the German middle class self-destruction.
} 
is evident. The most visible growth is among the private sector lower class and the higher service class. Nevertheless, during the 1990s and 2000s, stability seems to be the most salient trend among the adult population.

This apparent stability, represented by the fact that the size of the middle class who are 20-59 years old has remained the same for over two decades, masks a considerable generational gap. French society, in terms of social stratification, culture, and politics, is marked by a strong generational fracture between the first generation of the baby boomers (born between 1945 and 1955), who were young adults in May 1968 and during a period of full employment and fast growth, and the cohorts born after 1955 who faced a depressive period of strong unemployment during their youth, alongside wage moderation and a housing crisis, among other problems [Chauvel 2019]. These two periods of entry into the labor market produced divergent trends in the social structure, culture, and representations of the middle classes. When we compare the dynamics of cohorts who recently reached 50 years of age and those 20 years younger, we observe a complete divergence in life chances.

We collapse the middle class into four groups: upper versus lower, and public sector versus private sector. Their intrinsic transformations are independent. More specifically, the cohorts of the early baby boom, born around 1948, benefitted from a boom in the public intermediate middle class (an archetype of the new middle class), while the newer generations, born after 1955, faced a profound mismatch between the potential and real empirical expansion of the public sector intermediate middle class. This 'potential' expansion is assessed by the size of a particular social group if education, social origin, gender and region effects had remained the same since $1982^{12}$.

If we compare the theoretical and empirical changes of the different groups (Figure 9), the main result is that, for the fifty-something age group, the real and potential transformations are similar. On the contrary, for the younger group, the massive expansion of education went with a boom in the 'potential' intermediate public sector middle class, but empirically, there was little change. These findings cannot explain the anxiety among the middle classes - the 'angoisse des classes moyennes', a kind of collective 'status panic' [Mills 1951, p. 237], specifically visible in younger populations.

The evidence of this shrinking dynamic is different from the trend shown by Wright and Dwyer [Wright, Dwyer 2003] or Murphy and Oesch [Murphy, Oesch 2018] who focused on a unidimensional hierarchy, but the overall result is the same: the intermediate middle class shrinks.

Another central aspect is the comparison between the empirical trend and what would have happened if the effect of social origins (father's occupation), gender, and level of education had remained unchanged over the period. To answer this question, we fix at 1982 for each age group the effect of the three variables (origins, gender, education), and compute for each year the theoretical proportion of social groups required for the effect of the three characteristics to remain unchanged ${ }^{13}$. Each year, the new

\footnotetext{
12 We compute the expected results of the logistic model explaining social structure groupings by gender education, social origins and regions, with the coefficients pertaining to 1982 . These calculations are obtained separately for age groups and for middle class subgroups.

13 For the calculations, we use a multinomial logistic model explaining social destiny (social groups of occupation) in 1982 given three independent variables: gender, origin, education, and we assign the same coefficients for following years (we use the expected probabilities of belonging to the groups) to compute the percentage of the different groups resulting from the change of their characteristics.
} 
cohorts are better educated than the previous ones, come from families of higher origins, and, thus, we can expect an increase of access to higher positions; the cohort dynamics of the reduction of inequalities between women and men [Chauvel 2004] could imply a similar evolution. In reality, the most substantial changes are led by education.

Figure 9. Empirical and predicted percentage of upper-grade professionals (if qualifications maintained their value after 1982); CPIS = Service class 1 and CPIS+PI (professions intermédiaires) $=$ Service class $1+2), \%$

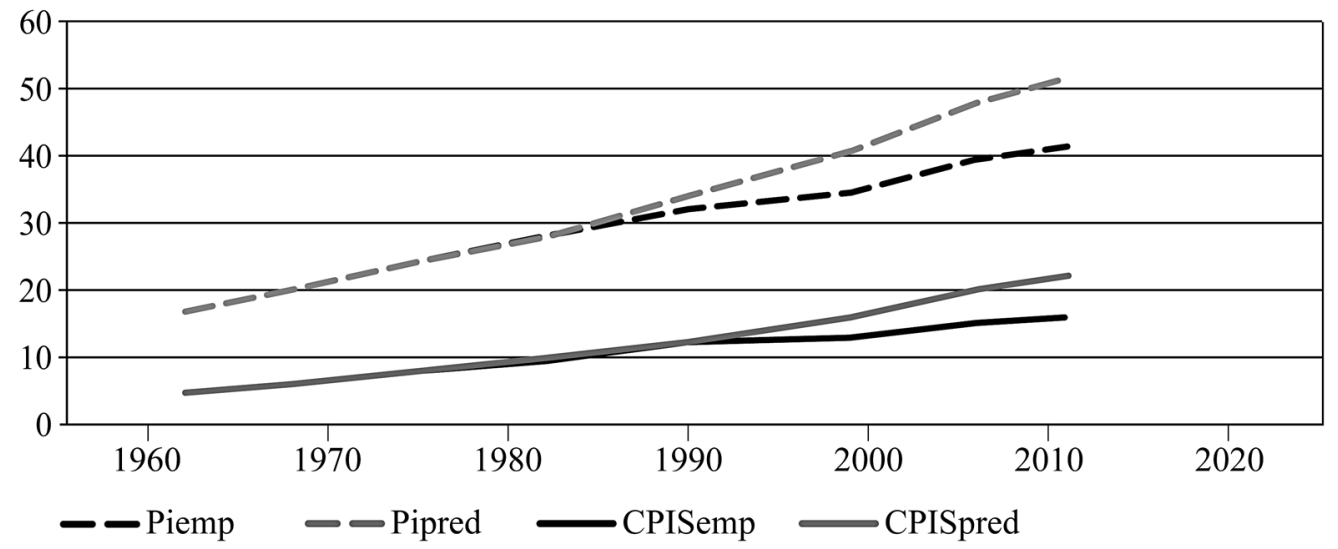

Note: Through logit models of upper middle class (CPIS "Cadres et professions intellectuelles supérieures") and of PCIS plus intermediate middle class ( PI "professions intermédiaires") predicted by gender, age group, level of education and father's socioeconomic category, we compare empirical reality of the trends and the counterfactual predicted trend where education is assumed to keep a constant role in terms of access to the middle class. The gap between empirical and predicted trends materializes a dynamics of overeducation where diploma have declining returns in terms of socioeconomic position.

Source: French censuses microdata from: Minnesota Population Center, Integrated Public Use Microdata Series, International: Version 6.1 [Machine-readable database], Minneapolis, University of Minnesota, 2016. Author's computations.

Since the first cohorts of the baby boom are better educated (the baccalauréat, the French SAT test, was passed by $15 \%$ of the 1935 birth cohort and $27 \%$ of the 1946 birth cohort), access to the higher service classes is expected to increase as well. However, in most social groups, the empirical curve is higher than the theoretical one: the actual increase of positions exceeded the growth of the usual candidates, and then to fill these positions, candidates with lower qualifications were required. The strongest gap between the empirical and theoretical increases appears for the private higher service class, but in relative terms, the empirical increase of the public higher service class is stronger.

Conversely, changes in the 30 to 35 year-old age group point to a less optimistic trend: the expansion of the level of education is strong, and the theoretical curves generally rise. However, the drastic reorganization of the welfare and interventionist state produced a strong decline in the public lower middle class, which was the archetype of the new middle class. 


\section{The quartering of the middle classes}

The demographic challenge where the number of potential candidates (given the level of education) exceeds the number of empty slots to be filled inside the "new intermediate middle class' positions, creates a strong trend of educational downgrading, i.e. the declining value of education in terms of prestige and position, is just one facet of the phenomenon. The other is the collective decline of the value of wages compared to the value of assets, where a middle-class wage earner shares with the working class the problem of the declining value of their work. Long-term data on the average value of net wages by social groups offer a clear vision of the problems of the wage earning middle class (Figure 10).

Figure 10. Net yearly average wage of full-time full-year employed wage earners of 4 social groups (constant euros, 2016) (upper-grade professionals = Service class 1 , lower-grade professionals = Service class 2 , routine service $=$ service sector workers; working $=$ industrial sector workers)

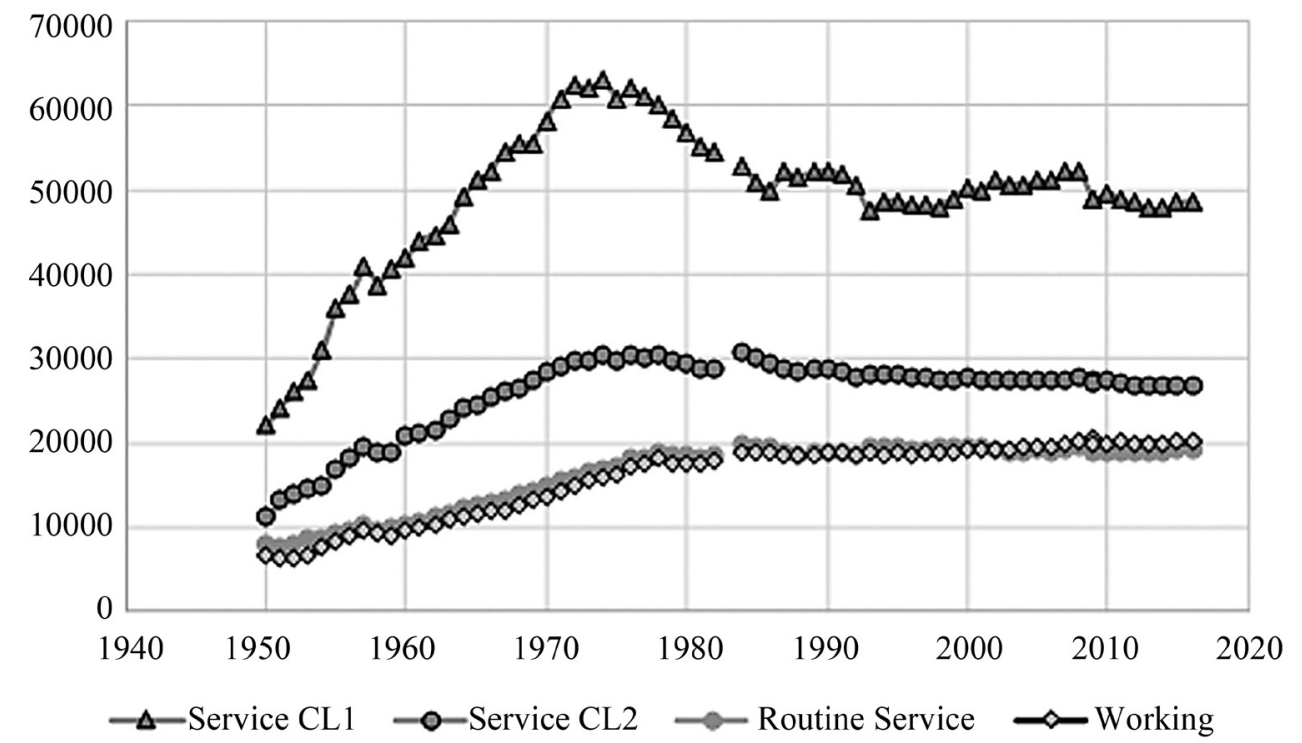

Source: INSEE series longues sur les salaires.

A long-term analysis of wage incomes, capital incomes and fluctuations in asset values [Piketty (2) 2001] shows that the post-Second World War period was marked by the increasing frequency of home ownership among middle-class wage earners, even without family support, due to high wages and low capital costs. On the contrary, the last twenty years have been marked by an increase in rental costs and property prices. Consequently, new cohorts of adults, even with higher incomes, cannot expect better housing than their parents. For older cohorts, the trend is positive since the value of their former accumulation increases; for young adults, economic dependence 
on the family is strengthened and the capacity for independence through work alone declines. This economic dependence could contribute to declining fertility rates in countries such as Spain, Italy, and Germany.

These constraints on access to capital (such as housing, via rent or acquisition) create a division between the children of families who have access to accumulation and those who do not (Figure 11). In France, between 2000 and 2017, the significance of household income as an explanatory factor is declining; heritage or inter-vivo gifts are better explanatory variables of wealth inequalities [Cordier, Houdré, Rougerie 2006; Chauvel 2019].

This point underlines the new fragmentation inside the middle classes between wage earners who have an intermediate level of cultural capital and no family support (which was typical of the new middle class of the 1960s, but is causing real difficulties today), and the strata of the privileged upper middle class who have better positions in the market economy and have access to patrimony. Such a situation goes hand in hand with less meritocratic and more unequal configurations of development [Chauvel, Bar-Haim, Hartung, van Kerm 2018].

Figure 11. Diverging costs of housing: real housing price index (dotted lines) and real household incomes index (thin lines) in 9 countries

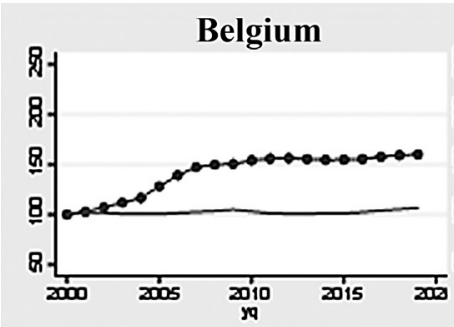

Finland
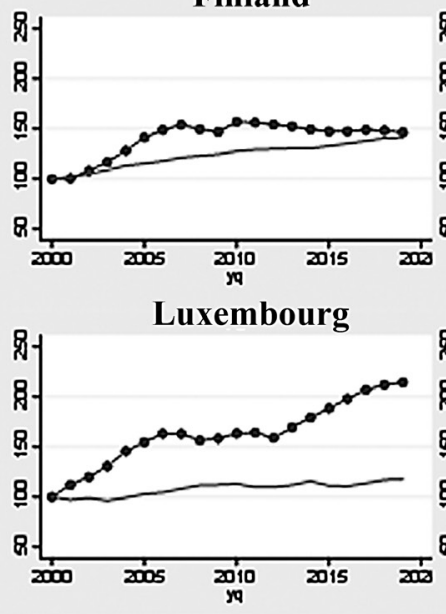

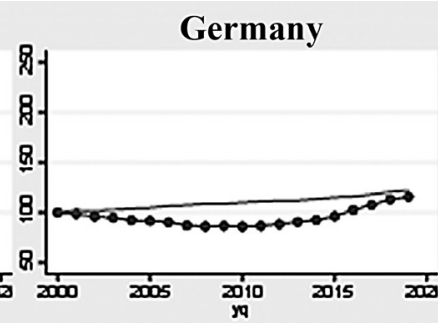

France

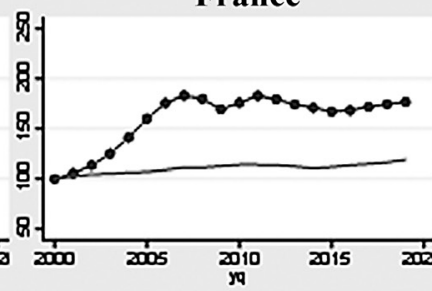

China

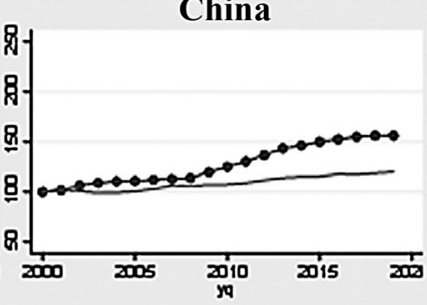

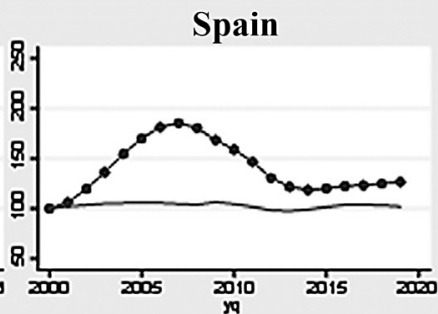

Italy

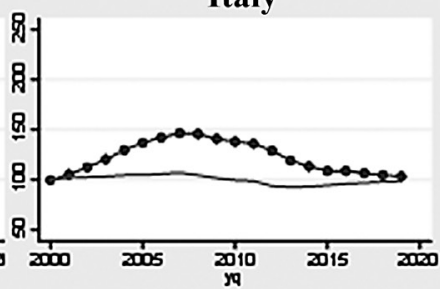

United States

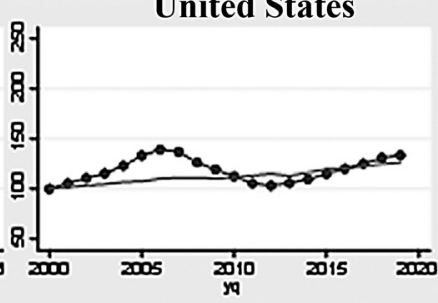

Note: $\mathrm{y}$-axis: Housing index and household incomes adjusted for inflation, indexed to year $2000(\mathrm{y}=100)$.

Source: International House Price Database, Federal Reserve Bank of Dallas. Data described in [Mack, Martínez-García 2011]. 
Generalizing the Wealth to Income Ratio (WIR) [Stiglitz 1969] to a more accurate measurement of the elites' transformation, the expansion of patrimony value relative to wage value in France generated a massive expansion of the Top Wealth to Income Ratio (TWIR): for the top $1 \%$ of wealth owners, the number of years of income their net accumulation is worth has jumped from 72 to 153 over 25 years (Figure 12). In countries like the US where the inequality of wealth increased massively between the top of distribution and median wealth, we observe a parallel expansion of the TWIR from 140 years to more than 300. After 1995, Russia experienced a similar trend, in a very different context, since the average income in Russia did not stagnate (as it did in France and the US) but increased by 230\% between 2000 and 2015, due to the impressive Russian economic recovery after the post-Soviet transition where many Russians experienced very difficult times [Gerber, Hout 1998].

Figure 12 . Top wealth (the top $1 \%$ of the population's average net wealth) to average income ratio TWIR in Russia, France and the US

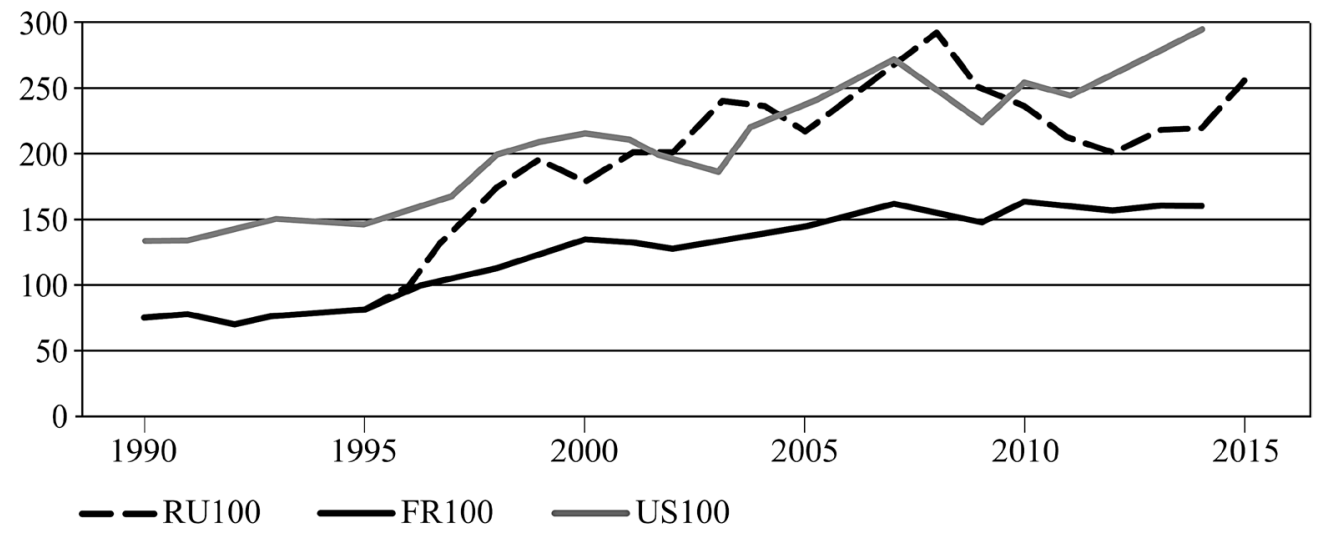

Source: Authors' calculations based on the WID database, https://wid.world/, see [Alvaredo et al. 2017]. The TWIR expresses the average wealth of the top $1 \%$ in number of years of average income accumulation.

\section{Conclusion}

The diagnosis of the European new middle class squeeze is as follows: the average evolution shows no strong change because it aggregates the optimism of the generations of contemporary seniors, and a major U-turn for the younger ones, who face a clear decline at the intermediate level of the social hierarchy (the lower middle class). Such a dynamic, which is particularly clear in France, has a large impact on the legitimacy of the educational system. After 20 years of educational expansion, the average age at end of school is now 2 years older, and the impact of this heavier investment in the futureby both the state and families - is quite unclear. If the most prestigious and selective institutions of higher education, such as Ecole Normale Supérieure, Ecole Polytechnique, Sciences Po, and the most selective Business schools, continue to prepare a well-trained 
and protected élite, most standard non-selective universities face a crisis, with a radical devaluation of their qualifications [Forgeot, Gautié 1997]. This devaluation produces a paradoxical university rush: the lower the value of qualifications, the greater the necessity to acquire higher degrees. Over-education goes with educational disenchantment, as occurred in the US in the 1970s [Freeman 1976; Collins 2019].

In terms of downward mobility, compared to Americans, the French are less subject to intra-cohort disruption than to inter-generational declines. In other words, France is less a country of 'falling from grace' [Newman 1988 (1999)] than a country of the specific incapacity of the younger generation to inherit the wage earning middle class status of their parents, due to a lack of positions in the new middle class. These younger generations, often the children of upwardly mobile baby boobers, are more educated, and many are experiencing downward dynamics of lower middle-class positions; this contradiction is likely to produce a kind of generational dismemberment of the new middle class. If the French social structure seems to have been stable in recent decades, the young face a collective concern of a shrinking new middle class. Their parents, who are growing increasingly conscious of the challenges of the next generation, are likely to share the pessimism of their children.

If wealth makes a difference and produces a larger number of potential heirs to a substantial fortune, this new trend is still seen as an additional injustice since patrimony is by definition the opposite of merit [Atkinson 2016]. The consequences of these trends, in political terms, are quite pervasive: the 2018 Yellow Vest movement, inspired by a radical critique of extreme social injustice, demonstrates the destabilization of the lower middle classes and of the younger generations in general. Revealing a deepening generational rift, these increasingly frequent earthquakes among the younger generations foreshadow the big one. By comparison with Western pessimistic trends, the Russian transformations over the last 20 years are much more optimistic since educational investments have received better rewards. In Western countries, a deep slowdown in this trend explains increasing tensions in the middle classes.

\section{References}

Aglietta M., Brender A. (1984) Les Métamorphoses de la Société Salariale, Paris: Calmann-Lévy. Alvaredo F., Chancel L., Piketty Th., Saez E., Zucman G. (2017) Global Inequality Dynamics: New Findings from WID.world. American Economic Review, vol. 107, no 5, pp. 404-409.

Aron R. (1969) Les Désillusions du Progrès, Essai sur la Dialectique de la Modernité, Paris: Calmann-Lévy.

Atkinson A. (2016) How To Spread The Wealth: Practical Policies For Reducing Inequality. Foreign Affairs, vol. 95, no 1, pp. 29-33.

Atkinson A.B., Glaude M., Olier L., Piketty Th. (1999) Inégalités Economiques. Rapports du Conseil d'Analyse Economique, no 33.

Bar-Haim E., Chauvel L., Hartung A. (2019) More Necessary and Less Sufficient: An AgePeriod-Cohort Approach to Overeducation in Comparative Perspective. Higher Education, no 78, pp. 479-499. DOI: 10.1007/s10734-018-0353-z

Barro R., Lee J.-W. (2013) A New Data Set of Educational Attainment in the World, 1950-2010. Journal of Development Economics, vol. 104(C), pp. 184-198.

Baverez N. (2003) La France Qui Tombe, Paris: Perrin.

Bernstein E. (1889) Die Voraussetzungen des Sozialismus und die Aufgaben der Sozialdemokratie, Stuttgart: J.H.W. Dietz Nachf.

Bidou C. (1984) Les Aventuriers du Quotidien: Essai sur les Nouvelles Classes Moyennes, Paris: Presses universitaires de France. 
Bihr A., Pfefferkorn R. (1995) Déchiffrer les Inégalités, Paris: Syros.

Bourdieu P. (1979) La Distinction, Critique Sociale du Jugement, Paris: Editions de Minuit.

Butler T. (with Robson G.) (2003) London Calling: The Middle Classes and the Remaking of Inner London, Oxford: Berg.

Castel R., Haroche C. (2001) Propriété Privée, Propriété Sociale, Propriété de Soi. Entretiens sur la Construction de l'Individu Moderne, Paris: Fayard.

Charle C. (2002) The Middle Classes in France: Social and Political Functions of Semantic Pluralism from 1870-2000. Social Contracts under Stress. The Middle Classes of America, Europe and Japan at the Turn of the Century (eds. Zunz O., Schoppa L., Hiwatari N.), New York: Russell Sage Foundation, pp. 66-88.

Chauvel L. (1995) Inégalités Singulières et Plurielles: l'Evolution de la Courbe de Répartition des Revenus. Revue de l'OFCE, no 55, pp. 211-240.

Chauvel L. (1998) Fluidité et Espace Social: Mobilité Intergénérationnelle Nette, Distance Sociale des PCS (Professions et Catégories Socioprofessionnelles) et Multidimensionnalité des Hiérarchies. Cahier de l'Observatoire Sociologique du Changement. Available at: http://louis.chauvel.free.fr/Cahosc.pdf, accessed 22.06.2020.

Chauvel L. (2001) Un Nouvel Age de la Société Américaine? Dynamiques et Perspectives de la Structure Sociale aux Etats-Unis (1950-2000). Revue de l'OFCE, no 76, pp. 7-51.

Chauvel L. (2002 (2e édition)) Le Destin des Générations, Structure Sociale et Cohortes en France au XXe Siècle, Paris: PUF.

Chauvel L. (2004) Vers l'Egalité de Genre: Les Tendances Générationnelles sont-elles Irréversibles. Revue de l'OFCE, no 90, pp. 69-84.

Chauvel L. (1) (2006) Social Generations, Life Chances and Welfare Regime Sustainability. Changing France, The Politics that Markets Make (eds. Culpepper P.D., Hall P.A., Palier B.), Houndmills, New York: Palgrave Macmillan, pp. 150-175.

Chauvel L. (2) (2006) Les Classes Moyennes à la Dérive, Paris: Le Seuil.

Chauvel L. (2016) The Intensity and Shape of Inequality: The ABG Method of Distributional Analysis. Review of Income and Wealth, vol. 62, no 1, pp. 52-68.

Chauvel L. (2019) La Spirale du Déclassement. Les Désillusions des Classes Moyennes (second edition), Paris: Le Seuil.

Chauvel L., Bar-Haim E., Hartung A., van Kerm P. (2018) Increasing Inequality in Joint Income and Wealth Distributions in the United States 1995-2013. Luxembourg Wealth Study Data, Working Paper for the Atkinson User LIS Conference. Available at: http://www.lisdatacenter.org/wp-content/uploads/files/uc2018-s6-2.pdf, accessed 22.06.2020.

Chauvel L., Hartung A. (2016) Malaise in the Western Middle Classes. World Social Science Report 2016. Challenging Inequalities: Pathways to a Just World, pp. 164-169. Available at: https://unesdoc.unesco.org/ark:/48223/pf0000245860, accessed 22.06.2020.

Collins R. (2019) The Credential Society: An Historical Sociology of Education and Stratification, New York: Columbia University Press.

Cordier C., Houdré C., Rougerie C. (2006) Les Inégalités de Patrimoine des Ménages entre 1992 et 2004. Données Sociales, Paris: INSEE références, pp. 455-464.

Desrosières A., Thévenot L. (1988) Les Catégories Socioprofessionnelles, Paris: La Découverte. Duru-Bellat M. (2006) L'Inflation Scolaire: Les Désillusions de la Méritocratie, Paris: Le Seuil. Erikson R., Goldthorpe J.H. (1992) The Constant Flux. A Study of Class Mobility in Industrial Societies, Oxford: Clarendon Press.

Esping-Andersen G. (1990) The Three Worlds of Welfare Capitalism, Princeton, New Jersey: Princeton University Press.

Forgeot G., Gautie J. (1997) Insertion Professionnelle des Jeunes et Processus de Déclassement. Economie et Statistique, vol. 304, no 1, pp. 53-74.

Fourastié J. (1979) Les Trente Glorieuses ou la Révolution Invisible, Paris: Fayard.

Freeman R.B. (1976) The Overeducated American, New York: Academic Press.

Geiger Th. (1932) Soziologische Gegenwartsfragen, Heft 1: Die soziale Schichtung des Volkes. Soziographischer Versuch auf statistischer Grundlage, Stuttgart: Ferdinand Enke Verlag.

Gerber T.P., Hout M. (1998) More Shock than Therapy: Market Transition, Employment, and Income in Russia, 1991-1995. American Journal of Sociology, vol. 104, no 1, pp. 1-50. DOI: $10.1086 / 210001$ 
Goblot E. (1925) La Barrière et le Niveau, Paris: PUF.

Gornick J., Jäntti M. (eds.) (2013) Income Inequality: Economic Disparities And The Middle Class In Affluent Countries, Stanford: Stanford University Press.

Guilluy Ch. (2016) Le Crépuscule de la France d'en Haut, Paris: Flammarion.

Heston A., Summers R., Aten B. (2001) Penn World Table Version 6.0, Center for International Comparisons at the University of Pennsylvania (CICUP), December 2001.

Killewald A., Pfeffer F.T., Schachner J.N. (2017) Wealth Inequality and Accumulation. Annual Review of Sociology, vol. 43, pp. 379-404.

Kocka J. (1981) Die Angestellten in der deutschen Geschichte: 1850-1980; vom Privatbeamten zum angestellten Arbeitnehmer, Göttingen: Vandenhoeck \& Ruprecht.

Krugman P. (1994) Europe Jobless, America Penniless? Foreign Policy, no 95, pp. 19-34.

Krugman P. (2005) French Family Values. The New York Times, July 29, 2005. Available at: https://www.nytimes.com/2005/07/29/opinion/french-family-values.html, accessed 22.06.2020.

Krugman P. (2009) A Continent Adrift. The New York Times, March 16, 2009. Available at: https://www.nytimes.com/2009/03/16/opinion/16krugman.html, accessed 22.06.2020.

Kuypers S., Marx I. (2018) Estimation of Joint Income-wealth Poverty: A Sensitivity Analysis. Social Indicators Research, vol. 136, pp. 117-137.

Lederer E., Marschak J. (1926) Der neue Mittelstand, in Grundriss der Sozialökonomik. Das soziale System des Kapitalismus. Grundriß der Sozialökonomik, IX. Abteilung, I. Teil. Tübingen, Mohr, pp. 120-141.

Mack A., Martínez-García E. (2011) A Cross-country Quarterly Database of Real House Prices: A Methodological Note. Federal Reserve Bank of Dallas, Globalization Institute. Working Papers 99. Available at: https://www.dallasfed.org/ /media/documents/institute/wpapers/2011/0099.pdf, accessed 22.06.2020.

Mau S. (2015) Inequality, Marketization and the Majority Class: Why Did the European Middle Classes Accept Neo-liberalism? Palgrave.

Mayer A.J. (1975) The Lower Middle Class as Historical Problem. The Journal of Modern History, vol. 47, no 3, pp. 409-436.

Mendras H. (1988) La Seconde Révolution Française: 1965-1984, Paris: Gallimard.

Mills C.W. (1951) White Collar: The American Middle classes, London: Oxford University Press.

Murphy E.C., Oesch D. (2018) Is Employment Polarisation Inevitable? Occupational Change in Ireland and Switzerland, 1970-2010. Work, Employment \& Society, British Sociological Association, vol. 32, no 6, pp. 1099-1117.

Newman K.S. (1988 (1999)) Falling from Grace: Downward Mobility in Age of Affluence, Berkeley: University of California Press.

Peugny C. (2009) Le Déclassement, Paris: Grasset.

Pfeuffer A., Schultheis F. (2002) Quelques Particularités Allemandes dans la Représentation Statistique du Monde Social. Sociétés Contemporaines, no 45-46, pp. 17-42.

Piketty Th. (1) (2001) Les Inégalités dans le Long Terme. Inégalités Economiques, Paris, pp. 137-204.

Piketty Th. (2) (2001) Les Hauts Revenus en France au XXe Siècle: Inégalités et Redistributions, 1901-1998, Paris: Grasset.

Piketty Th. (2014) Capital in the Twenty First Century, Cambridge: Belknap Press.

Piketty Th. (2020) Capital and Ideology, Cambridge: Harvard University Press.

Saez E., Zucman G. (2016) Wealth Inequality in the United States since 1913: Evidence from Capitalized Income Tax Data. The Quarterly Journal of Economics, vol. 131, no 2, pp. 519-578.

Savage M. (2015) Social Class in the 21st Century, London: Pelican.

Schmoller G. (1897) Was Verstehen Wir unter dem Mittelstande? Hat er im 19. Jahrhundert zu oder abgenommen? Göttingen: Vandenhoeck und Ruprecht.

Simmel G. (1905) Philosophie der Mode. Gesamtausgabe, vol. 10, pp. 7-38.

Skocpol T. (2000) The Missing Middle: Working Families and the Future of American Social Policy, New York: Norton.

Smith T.B. (2004) France in Crisis: Welfare, Inequality, and Globalization since 1980, Cambridge: Cambridge University Press.

Stiglitz J.E. (1969) Distribution of Income and Wealth among Individuals. Econometrica: Journal of the Econometric Society, vol. 37, no 3, pp. 382-397. 
Szreter S.R.S. (1993) The Official Representation of Social Classes in Britain, the United States and France: The Professional Model and 'Les Cadres'. Comparative Studies in Society and History, vol. 35, no 2, pp. 285-317.

Thelen K. (2014) Varieties of Liberalization and the New Politics of Social Solidarity, Cambridge: Cambridge University Press.

Todd E. (1995) Aux Origines du Malaise Politique Français. Les Classes Sociales et Leur Représentation. Le Débat, no 83, pp. 98-120.

Touraine A. (1969) La Société Post-industrielle, Paris: Denoël.

Wright E.O., Dwyer R. (2003) The Patterns of Job Expansions in the USA: A Comparison of the 1960s and 1990s. Socioeconomic Review, vol. 1, pp. 289-325.

Zunz O., Schuppa L., Hiwatari N. (eds.) (2002) Social Contracts under Stress: The Middle Classes of America, Europe, and Japan at the Turn of the Century, New York: Russell Sage Foundation.

\title{
Западный средний класс под натиском: увядание государств всеобщего благосостояния, глобализация и снижающаяся отдача от образования
}

\author{
Л. ШОВЕЛЬ*
}

\begin{abstract}
*Луи Шовель - профессор социологии, руководитель Института исследований социально-экономического неравенства, Университет Люксембурга; научный сотрудник, Центр социологических исследований, Парижский институт политических наук. Адрес: MSH 11 porte des Sciences, 4366, Esch-Belval, Luxembourg. E-mail: louis.chauvel@uni.lu
\end{abstract}

Цитирование: Chauvel L. (2020) The Western Middle Classes under Stress: Welfare State Retrenchments, Globalization, and Declining Returns to Education. Mir Rossii, vol. 29, no 4, pp. 85-111. DOI: 10.17323/1811-038X-2020-29-4-85-111

Проблемы многополярности и многокритериальности выделения и исследования средних классов имеют давние традиции, которые представляются весьма ценными для понимания изменений в структуре средних классов в континентальной Европе за последние 20 лет. Продолжающееся расширение так называемого нового среднего класса наемных рабочих в 1960-1990-е гг. сегодня уже кажется не более чем мечтой. Нынешние тенденции в социальной структуре европейских обществ корректнее было бы охарактеризовать как тенденции к репатримониализации, предполагающей U-образный разворот к ценности среднеквалифицированного труда и интенсивности наследования семейного капитала.

Эта статья обращается к трем моментам. Во-первых, к необходимости описания вышеуказанных процессов в специфически европейском контексте обществ среднего класса и, в частности, переосмысления системы «средних классов» в рамках подъема и падения развитых государств всеобщего благосостояния. Во-вторых, к анализу трех важных аспектов социальных тенденций, стоявших за формированием «обществ наемного среднего класса» в 1960-1990-е гг. В этот период экономическое процветание, 
социальная гомогенизация общества и социальная защита были ключевыми обстоятельствами, способствовавшими расширению средних классов. Этому также содействовали усиление меритократических тенденций в системе образования и на рынке труда, а также увеличение удельного веса трудовых доходов по сравнению с рентой от владения и распоряжения собственностью (т. е. процесс депатримониализации). После 1990-х гг. многие из этих тенденций были оборваны и даже развернулись вспять, что повлекло за собой сужение средних классов. В-третьих, в статье анализируются демографические и социальные последствия трансформаций в социальной структуре.

Помимо этого, обращается внимание на потерю интереса значительной части среднего класса к поддержанию сложившегося социального порядка, в свете чего проблема социальной стабильности также нуждается в переосмыслении.

Ключевые слова: средний класс, неравенство, богатство, государство всеобщего благосостояния, социальные тенденции, поколения, классы

\section{Литература}

Aglietta M., Brender A. (1984) Les Métamorphoses de la Société Salariale, Paris: Calmann-Lévy. Alvaredo F., Chancel L., Piketty Th., Saez E., Zucman G. (2017) Global Inequality Dynamics: New Findings from WID.world // American Economic Review, vol. 107, no 5, pp. 404-409.

Aron R. (1969) Les Désillusions du Progrès, Essai sur la Dialectique de la Modernité, Paris: Calmann-Lévy.

Atkinson A. (2016) How To Spread The Wealth: Practical Policies For Reducing Inequality // Foreign Affairs, vol. 95, no 1, pp. 29-33.

Atkinson A.B., Glaude M., Olier L., Piketty Th. (1999) Inégalités Economiques // Rapports du Conseil d'Analyse Economique, no 33.

Bar-Haim E., Chauvel L., Hartung A. (2019) More Necessary and Less Sufficient: An AgePeriod-Cohort Approach to Overeducation in Comparative Perspective // Higher Education, no 78, pp. 479-499. DOI: $10.1007 /$ s10734-018-0353-z

Barro R., Lee J.-W. (2013) A New Data Set of Educational Attainment in the World, 1950-2010 // Journal of Development Economics, vol. 104(C), pp. 184-198.

Baverez N. (2003) La France Qui Tombe, Paris: Perrin.

Bernstein E. (1889) Die Voraussetzungen des Sozialismus und die Aufgaben der Sozialdemokratie, Stuttgart: J.H.W. Dietz Nachf.

Bidou C. (1984) Les Aventuriers du Quotidien: Essai sur les Nouvelles Classes Moyennes, Paris: Presses universitaires de France.

Bihr A., Pfefferkorn R. (1995) Déchiffrer les Inégalités, Paris: Syros.

Bourdieu P. (1979) La Distinction, Critique Sociale du Jugement, Paris: Editions de Minuit.

Butler T. (with Robson G.) (2003) London Calling: The Middle Classes and the Remaking of Inner London, Oxford: Berg.

Castel R., Haroche C. (2001) Propriété Privée, Propriété Sociale, Propriété de Soi. Entretiens sur la Construction de l'Individu Moderne, Paris: Fayard.

Charle C. (2002) The Middle Classes in France: Social and Political Functions of Semantic Pluralism from 1870-2000 // Social Contracts under Stress. The Middle Classes of America, Europe and Japan at the Turn of the Century (eds. Zunz O., Schoppa L., Hiwatari N.), New York: Russell Sage Foundation, pp. 66-88.

Chauvel L. (1995) Inégalités Singulières et Plurielles: l'Evolution de la Courbe de Répartition des Revenus // Revue de l'OFCE, no 55, pp. 211-240. 
Chauvel L. (1998) Fluidité et Espace Social: Mobilité Intergénérationnelle Nette, Distance Sociale des PCS (Professions et Catégories Socioprofessionnelles) et Multidimensionnalité des Hiérarchies // Cahier de l'Observatoire Sociologique du Changement // http://louis.chauvel.free.fr/Cahosc.pdf

Chauvel L. (2001) Un Nouvel Age de la Société Américaine? Dynamiques et Perspectives de la Structure Sociale aux Etats-Unis (1950-2000) // Revue de l'OFCE, no 76, pp. 7-51.

Chauvel L. (2002 (2e édition)) Le Destin des Générations, Structure Sociale et Cohortes en France au XXe Siècle, Paris: PUF.

Chauvel L. (2004) Vers l'Egalité de Genre: Les Tendances Générationnelles sont-elles Irréversibles // Revue de l'OFCE, no 90, pp. 69-84.

Chauvel L. (1) (2006) Social Generations, Life Chances and Welfare Regime Sustainability // Changing France, The Politics that Markets Make (eds. Culpepper P.D., Hall P.A., Palier B.), Houndmills, New York: Palgrave Macmillan, pp. 150-175.

Chauvel L. (2) (2006) Les Classes Moyennes à la Dérive, Paris: Le Seuil.

Chauvel L. (2016) The Intensity and Shape of Inequality: The ABG Method of Distributional Analysis // Review of Income and Wealth, vol. 62, no 1, pp. 52-68.

Chauvel L. (2019) La Spirale du Déclassement. Les Désillusions des Classes Moyennes (second edition), Paris: Le Seuil.

Chauvel L., Bar-Haim E., Hartung A., van Kerm P. (2018) Increasing Inequality in Joint Income and Wealth Distributions in the United States 1995-2013 // Luxembourg Wealth Study Data, Working Paper for the Atkinson User LIS Conference // http://www.lisdatacenter.org/wp-content/uploads/files/uc2018-s6-2.pdf

Chauvel L., Hartung A. (2016) Malaise in the Western Middle Classes // World Social Science Report 2016. Challenging Inequalities: Pathways to a Just World, pp. 164-169 // https://unesdoc.unesco.org/ark:/48223/pf0000245860

Collins R. (2019) The Credential Society: An Historical Sociology of Education and Stratification, New York: Columbia University Press.

Cordier C., Houdré C., Rougerie C. (2006) Les Inégalités de Patrimoine des Ménages entre 1992 et 2004 // Données Sociales, Paris: INSEE références, pp. 455-464.

Desrosières A., Thévenot L. (1988) Les Catégories Socioprofessionnelles, Paris: La Découverte. Duru-Bellat M. (2006) L'Inflation Scolaire: Les Désillusions de la Méritocratie, Paris: Le Seuil.

Erikson R., Goldthorpe J.H. (1992) The Constant Flux. A Study of Class Mobility in Industrial Societies, Oxford: Clarendon Press.

Esping-Andersen G. (1990) The Three Worlds of Welfare Capitalism, Princeton, New Jersey: Princeton University Press.

Forgeot G., Gautie J. (1997) Insertion Professionnelle des Jeunes et Processus de Déclassement // Economie et Statistique, vol. 304, no 1, pp. 53-74.

Fourastié J. (1979) Les Trente Glorieuses ou la Révolution Invisible, Paris: Fayard.

Freeman R.B. (1976) The Overeducated American, New York: Academic Press.

Geiger Th. (1932) Soziologische Gegenwartsfragen, Heft 1: Die soziale Schichtung des Volkes. Soziographischer Versuch auf statistischer Grundlage, Stuttgart: Ferdinand Enke Verlag.

Gerber T.P., Hout M. (1998) More Shock than Therapy: Market Transition, Employment, and Income in Russia, 1991-1995 //American Journal of Sociology, vol. 104, no 1, pp. 1-50. DOI: $10.1086 / 210001$

Goblot E. (1925) La Barrière et le Niveau, Paris: PUF.

Gornick J., Jäntti M. (eds.) (2013) Income Inequality: Economic Disparities And The Middle Class In Affluent Countries, Stanford: Stanford University Press.

Guilluy Ch. (2016) Le Crépuscule de la France d'en Haut, Paris: Flammarion.

Heston A., Summers R., Aten B. (2001) Penn World Table Version 6.0, Center for International Comparisons at the University of Pennsylvania (CICUP), December 2001.

Killewald A., Pfeffer F.T., Schachner J.N. (2017) Wealth Inequality and Accumulation // Annual Review of Sociology, vol. 43, pp. 379-404.

Kocka J. (1981) Die Angestellten in der deutschen Geschichte: 1850-1980; vom Privatbeamten zum angestellten Arbeitnehmer, Göttingen: Vandenhoeck \& Ruprecht.

Krugman P. (1994) Europe Jobless, America Penniless? // Foreign Policy, no 95, pp. 19-34. 
Krugman P. (2005) French Family Values // The New York Times, July 29, 2005 // https:/www.nytimes.com/2005/07/29/opinion/french-family-values.html

Krugman P. (2009) A Continent Adrift // The New York Times, March 16, 2009 // https://www.nytimes.com/2009/03/16/opinion/16krugman.html

Kuypers S., Marx I. (2018) Estimation of Joint Income-wealth Poverty: A Sensitivity Analysis // Social Indicators Research, vol. 136, pp. 117-137.

Lederer E., Marschak J. (1926) Der neue Mittelstand, in Grundriss der Sozialökonomik. Das soziale System des Kapitalismus // Grundriß der Sozialökonomik, IX. Abteilung, I. Teil. Tübingen, Mohr, pp. 120-141.

Mack A., Martínez-García E. (2011) A Cross-country Quarterly Database of Real House Prices: A Methodological Note // Federal Reserve Bank of Dallas, Globalization Institute. Working Papers 99 // https://www.dallasfed.org/ /media/documents/institute/wpapers/2011/0099.pdf

Mau S. (2015) Inequality, Marketization and the Majority Class: Why Did the European Middle Classes Accept Neo-liberalism? Palgrave.

Mayer A.J. (1975) The Lower Middle Class as Historical Problem // The Journal of Modern History, vol. 47, no 3, pp. 409-436.

Mendras H. (1988) La Seconde Révolution Française: 1965-1984, Paris: Gallimard.

Mills C.W. (1951) White Collar: The American Middle classes, London: Oxford University Press.

Murphy E.C., Oesch D. (2018) Is Employment Polarisation Inevitable? Occupational Change in Ireland and Switzerland, 1970-2010 // Work, Employment \& Society, British Sociological Association, vol. 32, no 6, pp. 1099-1117.

Newman K.S. (1988 (1999)) Falling from Grace: Downward Mobility in Age of Affluence, Berkeley: University of California Press.

Peugny C. (2009) Le Déclassement, Paris: Grasset.

Pfeuffer A., Schultheis F. (2002) Quelques Particularités Allemandes dans la Représentation Statistique du Monde Social // Sociétés Contemporaines, no 45-46, pp. 17-42.

Piketty Th. (1) (2001) Les Inégalités dans le Long Terme // Inégalités Economiques, Paris, pp. 137-204.

Piketty Th. (2) (2001) Les Hauts Revenus en France au XXe Siècle: Inégalités et Redistributions, 1901-1998, Paris: Grasset.

Piketty Th. (2014) Capital in the Twenty First Century, Cambridge: Belknap Press.

Piketty Th. (2020) Capital and Ideology, Cambridge: Harvard University Press.

Saez E., Zucman G. (2016) Wealth Inequality in the United States since 1913: Evidence from Capitalized Income Tax Data // The Quarterly Journal of Economics, vol. 131, no 2, pp. 519-578.

Savage M. (2015) Social Class in the 21st Century, London: Pelican.

Schmoller G. (1897) Was Verstehen Wir unter dem Mittelstande? Hat er im 19. Jahrhundert zu oder abgenommen? Göttingen: Vandenhoeck und Ruprecht.

Simmel G. (1905) Philosophie der Mode // Gesamtausgabe, vol. 10, pp. 7-38.

Skocpol T. (2000) The Missing Middle: Working Families and the Future of American Social Policy, New York: Norton.

Smith T.B. (2004) France in Crisis: Welfare, Inequality, and Globalization since 1980, Cambridge: Cambridge University Press.

Stiglitz J.E. (1969) Distribution of Income and Wealth among Individuals // Econometrica: Journal of the Econometric Society, vol. 37, no 3, pp. 382-397.

Szreter S.R.S. (1993) The Official Representation of Social Classes in Britain, the United States and France: The Professional Model and 'Les Cadres' // Comparative Studies in Society and History, vol. 35, no 2, pp. 285-317.

Thelen K. (2014) Varieties of Liberalization and the New Politics of Social Solidarity, Cambridge: Cambridge University Press.

Todd E. (1995) Aux Origines du Malaise Politique Français. Les Classes Sociales et Leur Représentation // Le Débat, no 83, pp. 98-120.

Touraine A. (1969) La Société Post-industrielle, Paris: Denoël.

Wright E.O., Dwyer R. (2003) The Patterns of Job Expansions in the USA: A Comparison of the 1960s and 1990s // Socioeconomic Review, vol. 1, pp. 289-325.

Zunz O., Schuppa L., Hiwatari N. (eds.) (2002) Social Contracts under Stress: The Middle Classes of America, Europe, and Japan at the Turn of the Century, New York: Russell Sage Foundation. 